\title{
Validation of six years of SCIAMACHY carbon monoxide observations using MOZAIC CO profile measurements
}

\author{
A. T. J. de Laat ${ }^{1,2}$, R. Dijkstra ${ }^{2}$, H. Schrijver ${ }^{2}$, P. Nédélec ${ }^{3}$, and I. Aben ${ }^{2}$ \\ ${ }^{1}$ Royal Netherlands Meteorological Institute (KNMI), de Bilt, The Netherlands \\ ${ }^{2}$ SRON Netherlands Institute for Space Research, Utrecht, The Netherlands \\ ${ }^{3}$ Centre National de la Recherche Scientifique (CNRS), Universite Paul Sabatier, Laboratoire d'aérologie, Toulouse, France
}

Correspondence to: A. T. J. de Laat (laatdej@knmi.nl)

Received: 31 January 2012 - Published in Atmos. Meas. Tech. Discuss.: 29 February 2012

Revised: 25 July 2012 - Accepted: 7 August 2012 - Published: 5 September 2012

\begin{abstract}
This paper presents a validation study of SCanning Imaging Absorption SpectroMeter for Atmospheric CartograpHY (SCIAMACHY) carbon monoxide (CO) total column measurements from the Iterative Maximum Likelihood Method (IMLM) algorithm using vertically integrated profile aircraft measurements obtained within the MOZAIC project for the six year time period of 2003-2008.

Overall we find a good agreement between SCIAMACHY and airborne measurements for both mean values - also on a year-to-year basis - as well as seasonal variations. Several locations show large biases that are attributed to local effects like orography and proximity of large emission sources. Differences were detected for individual years: 2003, 2004 and 2006 have larger biases than 2005, 2007 and 2008, which appear to be related to SCIAMACHY instrumental issues but require more research. Results from this study are consistent with, and complementary to, findings from a previous validation study using ground-based measurements (de Laat et al., 2010b). According to this study, the SCIAMACHY data, if individual measurements are of sufficient quality - good signal-to-noise, can be used to determine the spatial distribution and seasonal cycles of CO total columns over clean areas. Biases found over areas with strong emissions (Africa, China) could be explained by low sensitivity of the instrument in the boundary layer and users are recommended to avoid using the SCIAMACHY data while trying to quantify $\mathrm{CO}$ burden and/or retrieve $\mathrm{CO}$ emissions in such areas.
\end{abstract}

\section{Introduction}

The SCIAMACHY instrument (SCanning Imaging Absorption SpectroMeter for Atmospheric CartograpHY; launched March 2002) onboard of the ENVISAT satellite (Bovensmann et al., 1999) has been providing carbon monoxide (CO) measurements based on reflected sunlight measurements in the short-wave infrared around $2.3 \mu \mathrm{m}$ from 2003 onwards. As of this moment, from the perspective of instrument characteristics six years of reliable data is available (2003-2008).

Initially, several algorithms were developed by different research groups and some initial evaluation was presented, indicating that SCIAMACHY was able to measure CO (Buchwitz et al., 2004, 2006, 2007; Dils et al., 2006; Sussmann and Buchwitz, 2005; Warneke et al., 2005; Gloudemans et al., 2006). The Iterative Maximum Likelihood Method developed at the Netherlands Institute for Space Research (SRON) has been further improved based on several additional studies (Gloudemans et al., 2008, 2009; de Laat et al., 2010a, b). More recently, new SCIAMACHY $\mathrm{CO}$ total column retrieval algorithms have been introduced (Gimeno Garcia et al., 2011; Liu et al., 2011).

De Laat et al. (2010b) presented an extensive validation of (IMLM) retrieval algorithm by comparing the SCIAMACHY measurements with ground-based spectrometer (GBS) observations for the five year period 2003-2007. In summary, de Laat et al. (2010b) found that overall there was a good agreement between SCIAMACHY and GBS observations for both mean values as well as seasonal variations. Validation results were robust with regard to the choices of the instrument-noise error filter, sampling area, and time 
averaging required for the validation of SCIAMACHY CO total column measurements.

However, de Laat et al. (2010b) also noted that validation was hampered by local emissions, station elevation effects and the large instrument-noise errors of individual SCIAMACHY measurements. Furthermore, it was noted that the spatial coverage of the GBS observations available for the validation of the 2003-2007 SCIAMACHY CO columns is sub-optimal for global validation purposes.

To further investigate the quality of SCIAMACHY IMLM $\mathrm{CO}$ we present a brief validation study using Measurements of OZone, water vapour, carbon monoxide and nitrogen oxides by in-service AIrbus aircraft (MOZAIC) (Marenco et al., 1998). MOZAIC provides CO vertical profiles at ascends and descends around airports that can be converted to partial $\mathrm{CO}$ columns - as the aircrafts do not observe beyond about $12 \mathrm{~km}$ altitude. The missing partial column above $12 \mathrm{~km}$ can be quantified from model simulations to derive a total $\mathrm{CO}$ column that can be compared with the SCIAMACHY measurements. The MOZAIC measurements provide a different independent dataset to compare with, and measurements cover areas not sampled by the GBS network. In addition, most MOZAIC profile measurements used for validation are made close to large cities and industrialized regions - both important sources of $\mathrm{CO}$ emissions. Validation with MOZAIC data thus provides crucial information on the ability of SCIAMACHY to measure near surface $\mathrm{CO}$, which is important for estimating $\mathrm{CO}$ emissions from satellite measurements. The GBS network used in the validation study by de Laat et al. (2010b) is mostly located in scarcely populated regions. The validation period considered in this paper is 2003-2008, so compared to de Laat et al. (2010b) the year 2008 is now also included for which no previous validation study has been performed.

This paper is organized as follows. Section 2 describes the measurement data and transport model TM5, Sect. 3 presents the results of the comparison between SCIAMACHY and MOZAIC measurements which are discussed in Sect. 4. Section 5 ends the paper with some conclusions.

\section{Datasets}

\subsection{SCIAMACHY}

For this study we use SCIAMACHY CO total columns retrieved with the IMLM algorithm version 7.4 in the shortwave infrared wavelength range between $2324.5-2337.9 \mathrm{~nm}$. The retrieval method described here is based on an Iterative Maximum Likelihood Method (IMLM). The forward model includes the atmospheric absorption and the instrument characteristics. The IMLM algorithm fits a model of the expected detector signal to the measurements by varying the total amounts of the trace gases that play a role in the selected retrieval window. For more algorithm details we re- fer to Gloudemans et al. $(2008,2009)$. This spectral region is sensitive to the whole column, with almost uniform sensitivity from $200 \mathrm{hPa}$ down to the surface (Gloudemans et al., 2008). In this paper, we assume that the SCIAMACHY $\mathrm{CO}$ total column is the real total column. Gloudemans et al. (2009) and de Laat et al. (2010a) provide a detailed discussion of SCIAMACHY averaging kernels and estimated that the effects of the SCIAMACHY CO a priori and averaging kernel were of the order of only a few percent which falls well within the estimated precision of SCIAMACHY measurements $(\sim 10 \%$, see further de Laat et al. (2010a), thereby justifying the assumption that SCIAMACHY CO total columns can be regarded as true total columns.

Single SCIAMACHY CO measurements have large instrument-noise errors - typically of the order of 10$100 \%$ of the total CO column value (de Laat et al., 2007). Hence, obtaining valuable information about $\mathrm{CO}$ from SCIAMACHY requires averaging multiple measurements and weighing them with their corresponding instrumentnoise errors. Several studies have shown that reducing the instrument-noise error by averaging multiple measurements yields useful information about CO (de Laat et al., 2006, 2007, 2010a, b; Gloudemans et al., 2006, 2009). De Laat et al. (2007) estimated the precisions of SCIAMACHY CO averages at approximately $1 \times 10^{17}$ molecules $\mathrm{cm}^{-2}$.

Similar to Gloudemans et al. (2009) and de Laat et al. (2010a, 2010b), we use SCIAMACHY CO observations over both land and oceans. Over land, only SCIAMACHY observations with cloud fraction $<20 \%$ are used. Over oceans, measurements over low altitude clouds between the surface and $800 \mathrm{hPa}$ are used. For both land and oceans, only measurements with instrument-noise errors $<$ $1.5 \times 10^{18}$ molecules $\mathrm{cm}^{-2}$ are used. Previous studies did not indicate systematic differences due to cloud fractions $<20 \%$ (de Laat et al., 2007). The effect of aerosols has previously been estimated to be less than 5\% (de Laat et al. 2007, and references therein).

This greatly improves spatio-temporal coverage as discussed in these papers. However, using measurements over low altitude clouds means that only the partial $\mathrm{CO}$ column above the cloud is observed. The missing below-cloud $\mathrm{CO}$ partial column is estimated from TM5 model results and added to the SCIAMACHY measurements where applicable. This contribution is quantified and summarized for all comparisons (see Table 1).

\subsection{MOZAIC}

MOZAIC was initiated in 1993 by European scientists, aircraft manufacturers and airlines to better understand the natural variability of the chemical composition of the atmosphere and how it is changing under the influence of human activity, with particular interest in the effect of aircraft emissions. MOZAIC consists of automatic and regular measurements of reactive gases by five long range passenger airliners. A large 
Table 1. $\Delta$ is the mean difference between SCIAMACHY and MOZAIC CO total columns $\left(10^{17}\right.$ molecules $\mathrm{cm}^{-2}$ and percentage). $\sigma$ is the mean root-mean-square difference between SCIAMACHY and MOZAIC CO total columns ( $10^{17}$ molecules cm $^{-2}$ and percentage). $R$ is the Pearson's correlation coefficient for the comparison between SCIAMACHY and MOZAIC CO total columns. $N$ is the total number of SCIAMACHY-MOZAIC comparison values. OCE is the estimated below cloud partial CO column for SCIAMACHY CO total column measurements over low altitude clouds over oceans $\left(10^{17}\right.$ molecules $\mathrm{cm}^{-2}$ and percentage). Note that for many grids, SCIAMACHY averages are based on both land and ocean measurements (see also PIX OCE). PIX OCE is the fractional part of SCIAMACHY measurements taken over low altitude ocean clouds for that particular grid box. UTLS is the TM5 estimated CO column above the maximum height of the MOZAIC profile (percentage of the MOZAIC total column). $Z=$ mean elevation with $8^{\circ} \times 8^{\circ}$ comparison grid (meters). The first column $(S)$ refers to the areas and cities in Fig. 2 and Table 2, respectively.

\begin{tabular}{|c|c|c|c|c|c|c|c|c|c|c|c|c|c|}
\hline$S$ & Lon & Lat & $\Delta\left(10^{17}\right)$ & $\Delta(\%)$ & $\sigma\left(10^{17}\right)$ & $\sigma(\%)$ & $R$ & $N$ & OCE $\left(10^{17}\right)$ & OCE (\%) & PIX OCE $(\%)$ & UTLS (\%) & $Z(\mathrm{~m})$ \\
\hline 1 & -120 & 34 & -3.7 & -17 & 4.1 & 19 & 0.61 & 75 & 1.6 & 8 & 94 & 6 & 407 \\
\hline 2 & -120 & 42 & -4.1 & -18 & 3.3 & 15 & 0.70 & 20 & 0.2 & 1 & 39 & 5 & 1165 \\
\hline 3 & -120 & 50 & -3.2 & -15 & 4.1 & 19 & 0.47 & 46 & $<0.1$ & $<1$ & 1 & 5 & 954 \\
\hline 4 & -96 & 34 & -3.0 & -14 & 4.5 & 21 & 0.41 & 90 & $<0.1$ & $<1$ & 1 & 9 & 263 \\
\hline 5 & -80 & 34 & -1.5 & -7 & 4.7 & 21 & 0.37 & 108 & 1.5 & 7 & 95 & 8 & 150 \\
\hline 6 & -88 & 42 & -3.3 & -14 & 3.6 & 15 & 0.54 & 35 & 0.0 & 0 & 0 & 7 & 228 \\
\hline 7 & -80 & 42 & -3.0 & -13 & 4.4 & 19 & 0.38 & 66 & 0.0 & 0 & 0 & 8 & 249 \\
\hline 8 & -72 & 42 & -3.0 & -12 & 3.5 & 14 & 0.50 & 143 & 3.7 & 15 & 99 & 9 & 127 \\
\hline 9 & -72 & 50 & -1.1 & -5 & 5.9 & 27 & -0.11 & 22 & 0.0 & 0 & 3 & 5 & 400 \\
\hline 10 & -64 & 10 & -4.3 & -19 & 5.5 & 25 & 0.07 & 42 & 1.0 & 5 & 100 & 10 & 116 \\
\hline 11 & 0 & 10 & -11.2 & -36 & 9.5 & 31 & 0.12 & 26 & $<0.1$ & $<1$ & 18 & 9 & 230 \\
\hline 12 & 16 & -22 & -1.1 & -7 & 4.1 & 27 & 0.56 & 211 & 0.2 & 1 & 59 & 10 & 917 \\
\hline 13 & 0 & 50 & -2.4 & -11 & 3.5 & 16 & 0.53 & 76 & 2.6 & 12 & 96 & 9 & 81 \\
\hline 14 & 8 & 50 & -1.4 & -6 & 4.3 & 20 & 0.48 & 114 & 1.2 & 6 & 77 & 6 & 362 \\
\hline 15 & 16 & 50 & -0.7 & -3 & 4.4 & 21 & 0.44 & 96 & $<0.1$ & $<1$ & 6 & 5 & 314 \\
\hline 16 & 32 & 18 & -5.4 & -25 & 5.2 & 24 & 0.08 & 14 & 0.0 & 0 & 0 & 10 & 429 \\
\hline 17 & 32 & 26 & -5.3 & -24 & 3.8 & 17 & 0.17 & 20 & $<0.1$ & $<1$ & 8 & 8 & 300 \\
\hline 18 & 32 & 34 & -5.2 & -24 & 3.6 & 16 & 0.41 & 62 & 0.4 & 2 & 56 & 11 & 326 \\
\hline 19 & 48 & 26 & -2.6 & -13 & 4.2 & 21 & 0.02 & 31 & $<0.1$ & $<1$ & 14 & 10 & 346 \\
\hline 20 & 56 & 26 & -3.5 & -17 & 3.2 & 15 & 0.42 & 68 & 0.1 & $<1$ & 39 & 12 & 520 \\
\hline 21 & 48 & 34 & -11.7 & -40 & 12.0 & 41 & -0.07 & 68 & $<0.1$ & $<1$ & 26 & 5 & 1119 \\
\hline 22 & 112 & 26 & -0.2 & 0 & 8.3 & 27 & 0.22 & 21 & 1.7 & 6 & 91 & 9 & 363 \\
\hline 23 & 120 & 34 & -3.0 & -9 & 9.1 & 27 & 0.35 & 30 & 3.9 & 12 & 98 & 12 & 56 \\
\hline 24 & 112 & 42 & -21.5 & -57 & 16.4 & 43 & 0.02 & 54 & 0.0 & 0 & 0 & 3 & 1132 \\
\hline 25 & 80 & 18 & -0.7 & -3 & 5.4 & 25 & 0.31 & 75 & 0.1 & $<1$ & 42 & 10 & 311 \\
\hline 26 & 80 & 26 & -3.9 & -16 & 4.7 & 20 & 0.05 & 53 & 0.0 & 0 & 0 & 10 & 648 \\
\hline 27 & 104 & 10 & -2.6 & -11 & 3.1 & 13 & 0.46 & 8 & 1.8 & 8 & 100 & 11 & 65 \\
\hline 28 & 96 & 18 & -4.3 & -17 & 7.8 & 31 & -0.52 & 15 & 0.7 & 3 & 72 & 9 & 360 \\
\hline 29 & 136 & 34 & -3.2 & -11 & 5.9 & 22 & 0.38 & 105 & 4.2 & 16 & 100 & 6 & 112 \\
\hline 30 & 144 & 34 & -3.7 & -14 & 5.2 & 19 & 0.35 & 57 & 3.5 & 13 & 100 & 5 & 9 \\
\hline
\end{tabular}

database of measurements (about 30000 flights since 1994) allows studies of chemical and physical processes in the atmosphere, validations of global chemistry transport models and satellite retrievals. MOZAIC data provide detailed climatologies of trace gases at $9-12 \mathrm{~km}$. MOZAIC data also provide frequent vertical profiles over a large number of airports. These vertical profile measurements of $\mathrm{CO}$ will be used to calculate $\mathrm{CO}$ total columns (see further Sect. 2.4). Evaluation of MOZAIC $\mathrm{CO}$ measurements indicates a precision of $\pm 5 \%$, which is sufficiently accurate for validation purposes (Nedelec et al., 2003). For more information about the MOZAIC program see Marenco et al. (1998) or the website found at http://mozaic.aero.obs-mip.fr.

\subsection{Global chemistry-transport model TM5}

We use the TM5 chemistry-transport model for the years 2003 to 2008 to quantify various effects that are important for the comparison of SCIAMACHY and MOZAIC measurements. This model is an update from the TM4 model used in de Laat et al. (2007, 2010a, b) and Gloudemans et al. (2009). A detailed description of the model can be found in Huijnen et al. (2010). The horizontal resolution of this TM5 version is $3^{\circ} \times 2^{\circ}$ longitude-latitude with 34 vertical levels. Meteorological ECMWF operational analysis input fields used in TM5 are pre-processed as described in Bregman et al. (2003). Biomass burning emissions are taken from the Global Fire Emissions Database, version 2 (GFEDv2) 8-day emission inventory (Van der Werf et al., 2006). The biomass burning emissions are distributed over different altitude ranges, depending on the latitude. The emission heights 
are similar to those described in Dentener et al. (2006), except the injection height in the tropics is increased to $2 \mathrm{~km}$ based on the evidence from recent satellite observations (e.g. Labonne et al., 2007). Anthropogenic emissions are based on the present-day anthropogenic emissions from the inventory from the RETRO project for the year 2000 (Schultz et al., 2007), while East Asian anthropogenic emissions are replaced by the REAS inventory (Ohara et al., 2007). For biogenic emissions climatological, values are used as derived from GEIA (Global Emissions Inventory Activity (Guenther et al., 1995)).

Validation of TM5 simulated CO against various types of measurements indicates that the model produces realistic seasonal cycles, but tends to underestimate $\mathrm{CO}$ in the Northern Hemisphere by 10-20\% depending on the season with larger differences during winter (Huijnen et al, 2010). This is consistent with findings of Elguindi et al. (2010) who report that the model tends to underestimate CO. Shindell et al. (2006) report that transport models in general tend to underestimate $\mathrm{CO}$. These discrepancies have been attributed to various causes, including hydrocarbon oxidation, uncertainties in the seasonal cycle of anthropogenic emissions and biomass burning injection heights and vertical redistribution. Elguindi et al. (2010) also suggest that part of the discrepancy might also be related to the fact that model grid boxes are compared to point measurements, particularly near the surface. Given that the model results are only used for quantifying missing subcolumns - either for SCIAMACHY measurements over clouded ocean scenes or for the CO column above the maximum MOZAIC profile altitude - the Northern Hemisphere TM5 model bias can be considered to be only of secondary importance.

\subsection{Post processing and selection criteria}

For comparing SCIAMACHY and MOZAIC measurements we use the following procedure, which is based on the methodology presented in de Laat et al. (2010b).

MOZAIC profiles are converted to partial columns. In order to ensure that the MOZAIC profile measurements are representative for a significant part of the troposphere, we only select profiles that start below $800 \mathrm{hPa}$ and measure at least up to $300 \mathrm{hPa}$. The missing partial column above the highest altitude where MOZAIC measures is estimated from TM5 model results. For each MOZAIC CO profile, the collocated model column above the maximum altitude of the MOZAIC profile is calculated, shown in Fig. 1. For more than $95 \%(99 \%)$ of the CO profiles, this subcolumn contributes less than $20 \%$ (30\%) of the total column. Considering that TM5 model biases in upper atmospheric $\mathrm{CO}$ are not larger than 10-20\% (Huijnen et al., 2010), biases in the total columns for the combination of MOZAIC and TM5 data that can be attributed to biases in TM5 cannot be larger than a few percent.

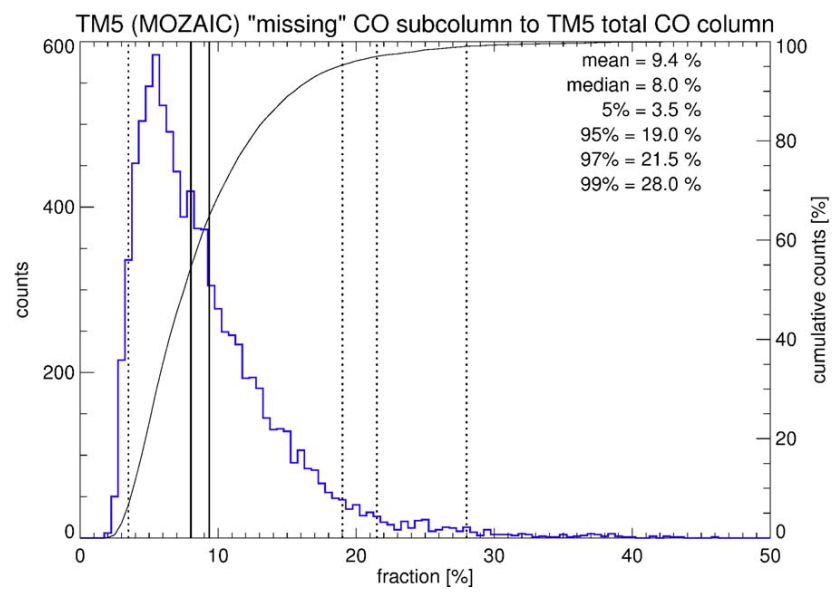

Fig. 1. Probability distribution of the partial CO column "missed" by MOZAIC due to the maximum altitude of MOZAIC CO profiles based on collocated TM5 simulated CO profiles. The "missing" partial column is expressed as a fraction of the total column. Indicated are also cumulative counts, the mean and median values (solid lines) and the $5 \%$ and 95/97/99 \% occurrence intervals (dashed lines).

Note that rather than adding the model estimate of the missing column to the MOZAIC partial column, it is also possible to scale the MOZAIC partial column with the modeled ratio of the total column over the modeled partial column. However, an evaluation of results from both methods yielded very similar total column estimates, indicating that results are robust with regard to the choice for correcting for the "missing" part in the MOZAIC profiles.

The comparison between SCIAMACHY and MOZAIC is hampered by the limited number of true collocations because of the SCIAMACHY spatial resolution and cloud cover and by the large instrument errors of individual SCIAMACHY measurements. De Laat et al. (2010b) introduced an averaging method in which for a given spatial area all SCIAMACHY measurements within a certain time interval were averaged. The length of the time interval was chosen such that instrument-noise error of the average SCIAMACHY CO columns was $1 \times 10^{17}$ molecules $\mathrm{cm}^{-2}$ or smaller, which is an estimate of the measurement accuracy based on both retrieval algorithm sensitivity studies as well as a detailed comparison of SCIAMACHY measurements with chemistrytransport model results (de Laat et al., 2007). MOZAIC measurements falling within this spatio-temporal "area" are simply averaged. De Laat et al. (2010b) studied the effect of area size on the comparison between ground-based measurements. There are two competing trade-offs: the larger the area, the more SCIAMACHY measurements available for averaging and thus the better the temporal resolution. On the other hand, the larger the area, the less representative the averages for that area for a single location. By varying the area size and comparing statical measures like correlations and root-mean-square difference, de Laat et al. (2010b) 


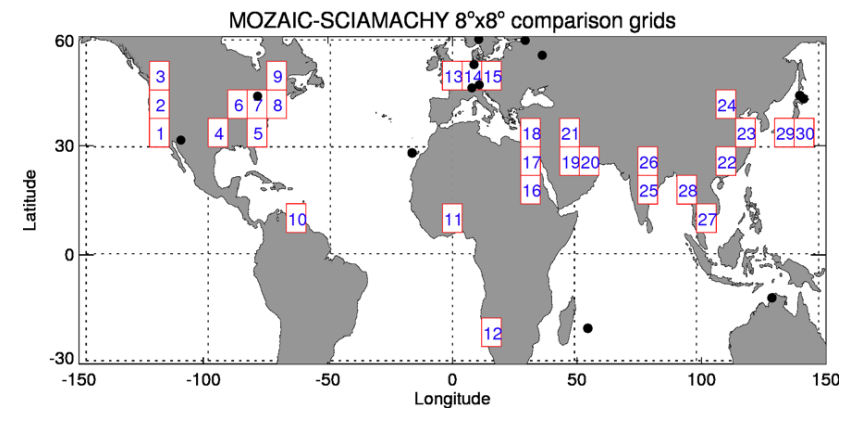

Fig. 2. Grid areas of $8^{\circ} \times 8^{\circ}$ with at least 25 MOZAIC comparison values for the period 2003-2008 (see Sect. 2 for explanation of how the comparison is devised). Grids are numbered from south to north and west to east for use in other figures. The black dots denote GBS locations used for validation of SCIAMACHY CO in de Laat et al. (2010b).

found that beyond an $8^{\circ} \times 8^{\circ}$ grid there is no gain. Hence, we compare SCIAMACHY CO with MOZAIC within an $8^{\circ} \times 8^{\circ}$ grid

Because MOZAIC flights are intermittent, the frequency of visits to airports by aircrafts that take part in MOZAIC varies considerably. Figure 2 provides a geographical overview of where $8^{\circ} \times 8^{\circ}$ grids in which MOZAIC data were sampled. Indicated are also the GBS locations used in de Laat et al. (2010b). Note that several GBS stations fall outside of the area shown here: Ny Alesund (Spitsbergen), Kiruna (northern Sweden), Lauder (New Zealand) and Arrival Heights (Antarctica). Clearly the GBS and MOZAIC networks complement each other. Table 2 provides a list of most frequently visited airports within the grid boxes shown in Fig. 2.

Biases that might be introduced by the area averaging methodology and effects of different grid comparison areas will be discussed later in this paper.

\section{Results}

\subsection{Time series}

Figure 3a-c present the comparison of MOZAIC and SCIAMACHY CO total column time series for the $8^{\circ} \times 8^{\circ}$ grid boxes in Fig. 2.

In general there is a reasonable to good agreement between both. We will discuss all grid box comparison, grouped according to geographical region.

The eastern USA boxes $(1,2,3)$ all show a good agreement. The seasonal cycle of location 1 (Los Angeles, San Francisco) is well reproduced by SCIAMACHY. Although there are fewer observations for region 3, IMLM still shows seasonal variations. Note particularly that for location 1 most SCIAMACHY observations are from above oceanic low clouds (Table 1), which are very persistent in this region.
Table 2. Most frequently visited airports for which ascending of descending MOZAIC flights fall within the $8^{\circ} \times 8^{\circ}$ grid box. ${ }^{\#} \mathrm{De}-$ pending on the airport location, the direction or descending or ascending MOZAIC flights can fall within different grid boxes, as is the case for Bangkok.

\begin{aligned} \hline No. & Cities \\ \hline 1 & Vancouver \\ 2 & Portland \\ 3 & San Francisco, Los Angeles \\ 4 & Houston, Dallas \\ 5 & Atlanta, Miami \\ 6 & Chicago, \\ 7 & Cincinatti, Detroit, Washington \\ 8 & Philadelphia, New York, Boston \\ 9 & Montreal, Toronto \\ 10 & Caracas \\ 11 & Lagos \\ 12 & Windhoek \\ 13 & London, Paris, Brussels \\ 14 & Munchen, Frankfurt \\ 15 & Vienna \\ 16 & Khartoum \\ 17 & Cairo \\ 18 & Tel Aviv \\ 19 & Riyadh, Kuwait \\ 20 & Dubai, Abu Dabi \\ 21 & Teheran \\ 22 & Hong Kong \\ 23 & Shanghai \\ 24 & Beijing \\ 25 & Madras, Hyderabad \\ 26 & Delhi \\ 27 & Bangkok \\ 28 & Bangkok \\ 29 & Osaka \\ 30 & Tokyo \\ \hline & \end{aligned}

For the central and eastern USA boxes (4-9) there is also a reasonable to good agreement. Seasonal cycles are reproduced. The comparison for locations 4, 5, 7 and 8 shows that during 2004 and 2006 SCIAMACHY columns are considerably smaller than MOZAIC. This phenomenon was also reported in de Laat et al. (2010b) for the comparison with the GBS measurements, and might point to some unresolved SCIAMACHY calibration issues. Also note that the year 2008 - which was not covered in de Laat et al. (2010b) - looks as good as any other year suggesting that SCIAMACHY data for 2008 is of similar quality as the other years.

Location 10 represents a tropical location (Caracas, Venezuela). Although SCIAMACHY measurements are comparable to MOZAIC measurements, this region shows not much seasonal variation in $\mathrm{CO}$ total columns, and the measurement sample is not very large. Also, here SCIAMACHY appears to underestimate CO in 2006. Note that all SCIAMACHY measurements come from observations 

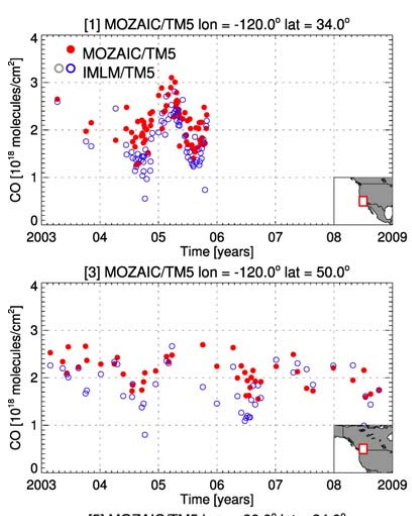

[5] MOZAIC $T$ MM IOn $=-80.0^{\circ}$ lat $=34.0^{\circ}$

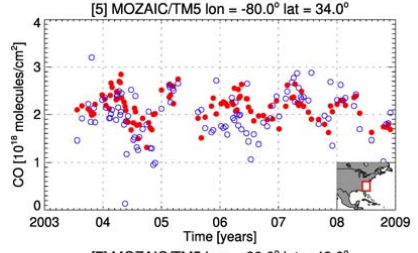

[7] MOZAIC $/$ MM lon $=-80.0^{\circ}$ lat $=42.0^{\circ}$

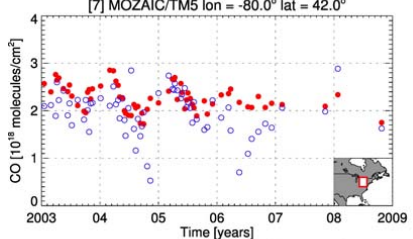

[9] MOZAIC $/$ TM5 lon $=-72.0^{\circ}$ lat $=50.0^{\circ}$

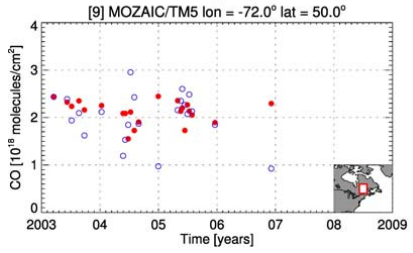

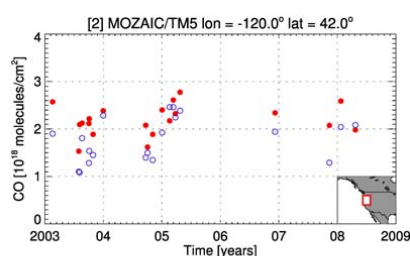

[4] $\mathrm{MOZAIC} / \mathrm{TM}$ lon $=-96.0^{\circ}$ lat $=34.0^{\circ}$

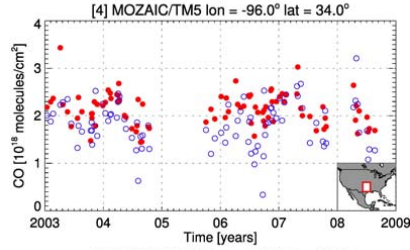

[6] MOZAIC $/$ M 5 lon $=-88.0^{\circ}$ lat $=42.0^{\circ}$

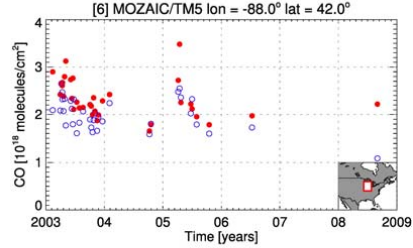

[8] MOZAIC $/$ MM lon $=-72.0^{\circ}$ lat $=42.0^{\circ}$
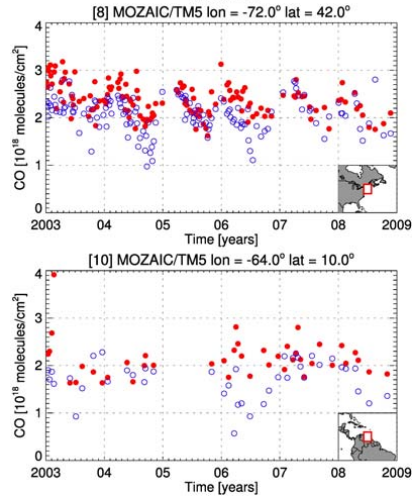

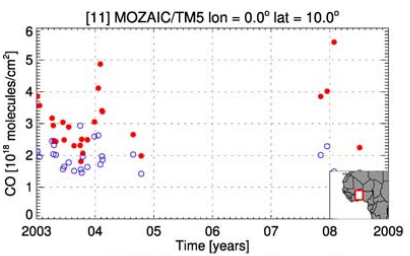

[13] MOZAIC $/$ TM 5 lon $=0.0^{\circ}$ lat $=50.0^{\circ}$

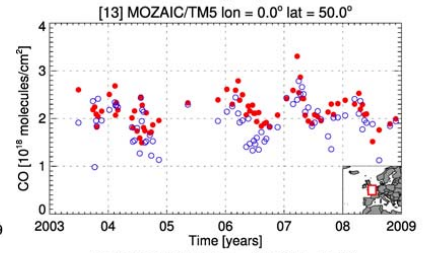

[15] MOZAIC $/ T M 5$ lon $=16.0^{\circ}$ lat $=50.0^{\circ}$

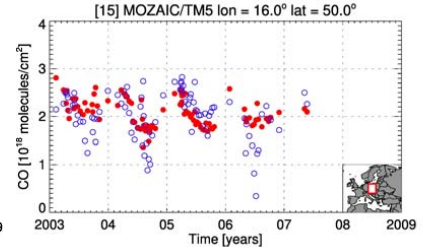

[17] MOZAIC $/$ TM5 lon $=32.0^{\circ}$ lat $=26.0^{\circ}$
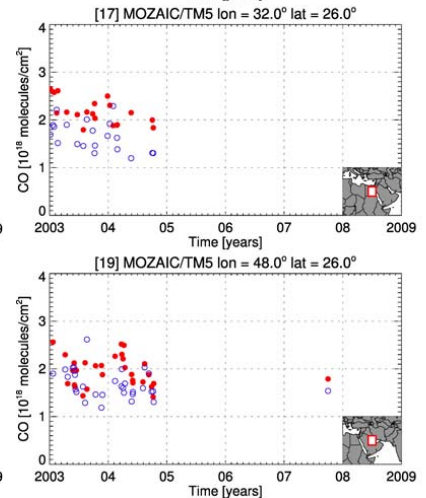

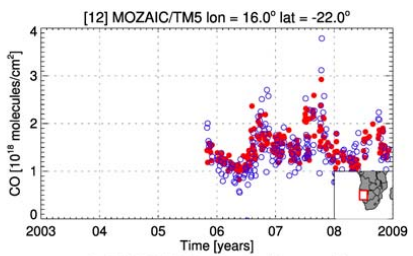

[14] $\mathrm{MOZAIC} / \mathrm{TM}$ lon $=8.0^{\circ}$ lat $=50.0^{\circ}$
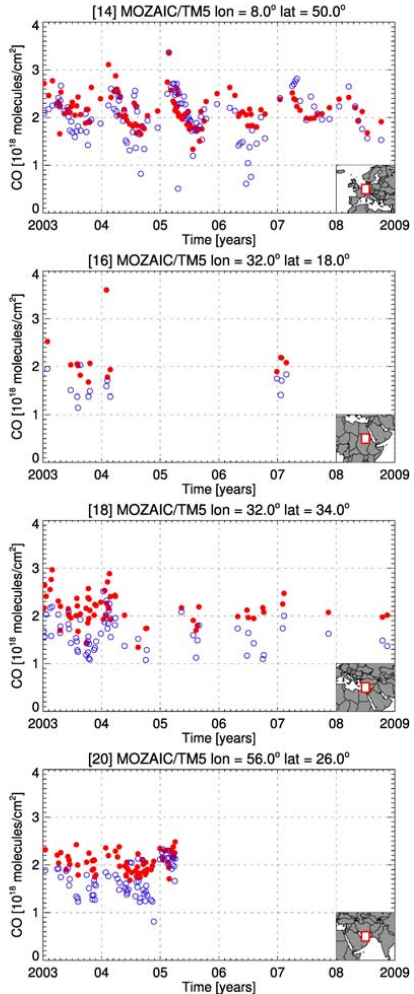

Fig. 3. Comparison of SCIAMACHY and MOZAIC time series for the period 2003-2008 for the $8^{\circ} \times 8^{\circ}$ grid boxes shown in, and numbered according to Fig. 2. The small map in the lower right corner of the panels denotes the grid box for orientation. The coordinates in the panel titles are the central longitude-latitude of the grid box. SCIAMACHY CO is denoted by the open circles, with the blue circles denoting measurements that have corresponding MOZAIC measurements. The filled red markers are the MOZAIC measurements.

over low altitude ocean clouds (Table 1), as the surface reflectance of the densely vegetated surrounding land - and thereby the signal-to-noise of the SCIAMACHY measurements - is small.

Location 11 represents the region around Lagos, Nigeria. This is a region with a strong seasonal cycle and high $\mathrm{CO}$ concentrations during the winter months (Redelsperger et al., 2006; Hopkins et al., 2009). Although for some years no MOZAIC measurements were made, the MOZAIC measurements show consistently larger $\mathrm{CO}$ columns than the SCIAMACHY measurements. A possible explanation might be that regional pollution - either anthropogenic or biomass burning, which is not represented by the SCIAMACHY averaging over the $8^{\circ} \times 8^{\circ}$ grid box - affects the MOZAIC measurements. TM5 results indeed indicate enhanced CO when averaging over a smaller area around Lagos.

Location 12 (Windhoek, Namibia) is in the Southern Hemisphere in a region that is strongly affected by sea- sonal biomass burning. Furthermore, the high surface reflectance of this area ensures a good signal-to-noise ratio for the SCIAMACHY measurements and thus many comparisons. Clearly, SCIAMACHY data show a very similar seasonal cycle and similar CO total columns, also in 2008. Overall, the agreement is very good.

Locations 13-15 are all located over Europe, a region that was already covered by the comparison between SCIAMACHY and GBS (de Laat et al., 2010b). Similar to the GBS results, there is a good agreement between SCIAMACHY and MOZAIC in terms of both the average total columns as well as the seasonal cycle, although especially for 2004 and 2006 there appears to be a bias in SCIAMACHY. The comparison for 2008 is similar to other years.

Locations 16-21 cover the Middle East region. Here, although there are fewer MOZAIC measurement, signal-tonoise of the SCIAMACHY measurements is as high as it can get due to the high reflectivity of the dry (semi) desert 

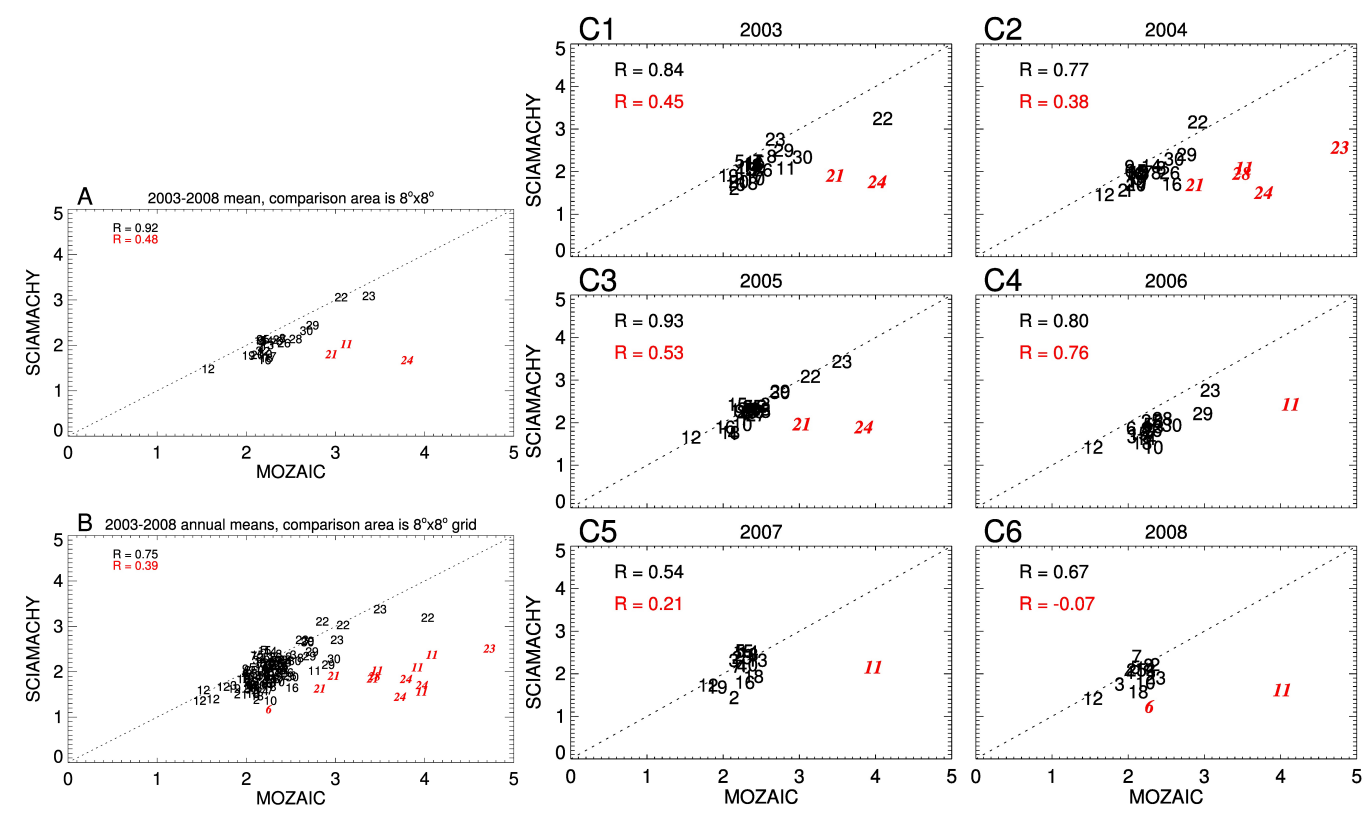

Fig. 4. blackboxplease give a section for figure 4. thank you.

surface. Overall, there is a reasonable agreement between SCIAMACHY and MOZAIC, although the seasonal cycles in this region are not very large. Furthermore, for several grid boxes, $\mathrm{CO}$ total columns from MOZAIC are larger than SCIAMACHY. This might be related to local pollution that is not represented by the SCIAMACHY averages and model results. Unlike Lagos (Nigeria; location 11), there is no indication of enhanced $\mathrm{CO}$ when averaging over a smaller area

Locations 22-24 are all over eastern China. Temporal coverage is limited, but concentrations for location $22(\sim$ Hong Kong) and 23 (Shanghai) are similar, and the large variations in $\mathrm{CO}$ total columns from one measurement to the next are also observed with SCIAMACHY. For location 24 - Beijing - MOZAIC shows much larger columns than SCIAMACHY. It is very likely that the particular local geographical conditions of Beijing can explain these differences, similar to Teheran, as TM5 $\left(3^{\circ} \times 2^{\circ}\right)$ results also do not indicate enhanced $\mathrm{CO}$ columns. Beijing borders a mountainous area which is much less densely populated and industrialized region, which is relevant given the $8^{\circ} \times 8^{\circ}$ grid box averaging of SCIAMACHY. Furthermore, this local geography enhances the buildup of pollution in the boundary layer around Beijing. Finally, the buildup of pollution and formation of a well known boundary layer haze over Beijing (Chan and Yao, 2008), in combination with dust storms from the interior of the continent (Eck et al., 2005), may limit the sensitivity of the SCIAMACHY measurements to the polluted boundary layer, as SCIAMACHY observes CO from reflected solar radiation around 2.3 micron and thus depends on light passing through CO pollution (M. Krijger, SRON, personal communication, 2012).
Locations 25 and 26 are over India. For location 25 over central Indian, SCIAMACHY and MOZAIC are comparable and show similar seasonal cycles and the year 2008 is similar to other years. For location 26 in Northern India, SCIAMACHY is smaller than MOZAIC, which in part may be related to, again, local pollution not represented by the SCIAMACHY averaging over $8^{\circ} \times 8^{\circ}$ grid boxes.

Locations 27 and 28 in southeastern Asia - Bangkok - show limited temporal coverage. Summertime CO total columns are similar, but SCIAMACHY misses some enhanced CO during the winter 2005-2006, although for years without MOZAIC measurements the SCIAMACHY measurements clearly show similar wintertime enhancement suggesting that maybe collocation issues like cloud contamination may have hampered SCIAMACHY observing the wintertime enhancement.

Finally, locations 29 and 30 over Japan show similar seasonal cycles. De Laat et al. (2010b) showed that for two GBS stations in northern Japan results were good, and this comparison confirms those findings.

\subsection{Statistics}

Figure 4a presents a scatter plot of the 2003-2008 average CO total columns for SCIAMACHY and MOZAIC comparisons presented in Fig. 3 and Table 1. The comparison shows a very good agreement between SCIAMACHY and MOZAIC, apart from three outliers which were already identified in Sect. 3.1 (Lagos, Teheran and Beijing). Disregarding these three locations by removing points for which the bias is larger than the arbitrary value of $1.0 \times 10^{18}$ molecules $\mathrm{cm}^{-2}$, we find a correlation of 0.92 for the comparison. However, 
there is a small CO total column bias between SCIAMACHY and MOZAIC of approximately $0.3 \times 10^{18}$ molecules $\mathrm{cm}^{-2}$ $(\sim 15 \%)$.

Figure $4 \mathrm{~b}$ shows the same comparison as in Fig. $4 \mathrm{a}$ but for all years separately. Similar to Fig. 4a, there is a good agreement between SCIAMACHY and MOZAIC if we disregard the three locations discussed above as well as location 6 (year 2008) and location 23 (year 2004). Disregarding these stations results in a correlation of 0.75 .

Figure $4 \mathrm{c}$ shows the comparison for all individual years. Disregarding the outliers discussed above results in correlation coefficients between 0.54 and 0.93 . Comparing year to year, we note that the years 2003, 2004 and 2006 have relatively large biases $\left(0.3-0.5 \times 10^{18}\right.$ molecules $\mathrm{cm}^{-2} ; \sim 10$ $25 \%$ ), which was already noted in the discussion of the time series. The years 2005, 2007 and 2008 have smaller biases $\left(0.1-0.2 \times 10^{18}\right.$ molecules $\left.\mathrm{cm}^{-2} ; \sim 3-10 \%\right)$.

Note that the year 2008 - not evaluated in de Laat et al. (2010b) - appears similar to the other years, although some locations with high $\mathrm{CO}$ total columns did not provide observations in 2008. However, removing stations with CO total columns larger than $2.5 \times 10^{18}$ molecules $\mathrm{cm}^{-2}$ for the years 2003-2007 yielded lower correlations similar to the 2008 correlation $(R=0.54-0.77)$, indicating that also the correlation for 2008 could be considered similar to the other years.

\section{Discussion}

The results from the comparison of SCIAMACHY with MOZAIC data are fully consistent with what was reported in de Laat et al. (2010b). Overall, there is a good agreement between the satellite and in-situ measurements. There are locations for which both observational records diverge. These differences are attributed to local effects and multiple explanations have been proposed although this was not investigated in more detail. One possibility is an incorrect assumption that the SCIAMACHY CO total column is the real total column (Sect. 2.1). Users should avoid using the SCIAMACHY CO data in areas with strongly polluted boundary layers until averaging kernels are re-assessed.

The comparison for 2003, 2004 and 2006 show larger biases than for the other years, a finding also noted in de Laat et al. (2010b). For the years 2003 and 2004, the most obvious explanation is the frequent "decontaminations" that took place. The SCIAMACHY channel 8 detectors are hampered by the buildup of a microscopic ice layer, which reduces signal-to-noise and increases scattering effects. During 2003 and 2004, the detector was frequently heated to evaporate the ice in the hope that the vapor would escape the spacecraft. After 2005, the frequent decontaminations were stopped and after an initial buildup the ice layer would remain stable. Hence, decontaminations cannot explain the bias observed for 2006. Another possible explanation might be a change in the available detector pixels. SCIAMACHY channel 8 suffers from radiation damage, which results in a steady reduction in the number of functioning detector pixels. The pixels used for the IMLM retrieval algorithm have to be actively varied to take this effect into account. This leads - over time - to different sets of pixels being used for the retrieval which might lead to different retrieval results. However, it is unclear as to whether the varying pixel mask can explain why for 2007 and 2008 the bias is smaller.

\section{Conclusions}

The validation of SCIAMACHY CO total columns with integrated in-situ CO profile measurements from the MOZAIC campaign shows a good to very good agreement. A few location show large biases, likely related to local effects. If SCIAMACHY measurements are of sufficient quality good signal-to-noise - then seasonal cycles can easily be discerned. Results from this study are consistent with those presented in de Laat et al. (2010b).

The comparison for individual years shows that the years 2003, 2004 and 2006 have larger biases than 2005, 2007 and 2008. For this study we extended the SCIAMACHY measurements with the year 2008. The validation with GBS measurements presented in de Laat et al. (2010b) only covered the years 2003-2007, and from this study we conclude that for 2008 SCIAMACHY provides good quality CO total column measurements as well.

Finally, we conclude that the MOZAIC network provides additional and crucial information for the validation of SCIAMACHY CO total columns. The network nicely complements the GBS network with a certain overlap - in particular in Europe and Japan - but also provides measurements at locations not covered by the GBS network - Middle East, south and southeast Asia, western USA, South Africa. Note that the GBS network covers some areas not visited by MOZAIC - high latitudes, Australia and New Zealand. Hence, both networks are mutually complementary.

Acknowledgements. We thank both referees for their valuable comments and help to improve the paper.

Edited by: R. Sussmann

\section{References}

Bovensmann, H., Burrows, J. P., Buchwitz, M., Frerick, J., Noel, S., Rozanov, V. V., Chance, K. V., and Goede, A. H. P.: SCIAMACHY - Mission Objectives and Measurement Modes, J. Atmos. Sci., 56, 127-150, 1999.

Bregman, B., Segers, A., Krol, M., Meijer, E., and van Velthoven, P.: On the use of mass-conserving wind fields in chemistry-transport models, Atmos. Chem. Phys., 3, 447-457, doi:10.5194/acp-3447-2003, 2003. 
Buchwitz, M., de Beek, R., Bramstedt, K., Noël, S., Bovensmann, H., and Burrows, J. P.: Global carbon monoxide as retrieved from SCIAMACHY by WFM-DOAS, Atmos. Chem. Phys., 4, 19451960, doi:10.5194/acp-4-1945-2004, 2004.

Buchwitz, M., de Beek, R., Noël, S., Burrows, J. P., Bovensmann, H., Schneising, O., Khlystova, I., Bruns, M., Bremer, H., Bergamaschi, P., Körner, S., and Heimann, M.: Atmospheric carbon gases retrieved from SCIAMACHY by WFM-DOAS: version $0.5 \mathrm{CO}$ and $\mathrm{CH}_{4}$ and impact of calibration improvements on $\mathrm{CO}_{2}$ retrieval, Atmos. Chem. Phys., 6, 2727-2751, doi:10.5194/acp6-2727-2006, 2006.

Buchwitz, M., Khlystova, I., Bovensmann, H., and Burrows, J. P.: Three years of global carbon monoxide from SCIAMACHY: comparison with MOPITT and first results related to the detection of enhanced CO over cities, Atmos. Chem. Phys., 7, 23992411, doi:10.5194/acp-7-2399-2007, 2007.

Chan, C. K. and Yao, X.: Air pollution in mega cities in China, Atmos. Environ., 42, 1-42, doi:10.1016/j.atmosenv.2007.09.003, 2008.

de Laat, A. T. J., Gloudemans, A. M. S., Schrijver, H., van den Broek, M. M. P., Meirink, J. F., Aben, I., and Krol, M.: Quantitative analysis of SCIAMACHY carbon monoxide total column measurements, Geophys. Res. Lett., 33, L07807, doi:10.1029/2005GL025530, 2006.

de Laat, A. T. J., Gloudemans, A. M. S., Aben, I., Krol, M., van der Werf, G., Meirink, J. F., and Schrijver, H.: SCIAMACHY Carbon Monoxide total columns: Statistical evaluation and comparison with CTM results, J. Geophys. Res., 112, D12310, doi:10.1029/2006JD008256, 2007.

de Laat, A. T. J., Gloudemans, A. M. S., Aben, I., and Schrijver, H.: Global evaluation of SCIAMACHY and MOPITT carbon monoxide column differences for 2004-2005, J. Geophys. Res., 115, D06307, doi:10.1029/2009JD012698, 2010a.

de Laat, A. T. J., Gloudemans, A. M. S., Schrijver, H., Aben, I., Nagahama, Y., Suzuki, K., Mahieu, E., Jones, N. B., Paton-Walsh, C., Deutscher, N. M., Griffith, D. W. T., De Mazière, M., Mittermeier, R. L., Fast, H., Notholt, J., Palm, M., Hawat, T., Blumenstock, T., Hase, F., Schneider, M., Rinsland, C., Dzhola, A. V., Grechko, E. I., Poberovskii, A. M., Makarova, M. V., Mellqvist, J., Strandberg, A., Sussmann, R., Borsdorff, T., and Rettinger, M.: Validation of five years (2003-2007) of SCIAMACHY CO total column measurements using ground-based spectrometer observations, Atmos. Meas. Tech., 3, 1457-1471, doi:10.5194/amt3-1457-2010, 2010b.

Dentener, F., Kinne, S., Bond, T., Boucher, O., Cofala, J., Generoso, S., Ginoux, P., Gong, S., Hoelzemann, J. J., Ito, A., Marelli, L., Penner, J. E., Putaud, J.-P., Textor, C., Schulz, M., van der Werf, G. R., and Wilson, J.: Emissions of primary aerosol and precursor gases in the years 2000 and 1750 prescribed data-sets for AeroCom, Atmos. Chem. Phys., 6, 4321-4344, doi:10.5194/acp-64321-2006, 2006.

Dils, B., De Maziére, M., Müller, J. F., Blumenstock, T., Buchwitz, M., de Beek, R., Demoulin, P., Duchatelet, P., Fast, H., Frankenberg, C., Gloudemans, A., Griffith, D., Jones, N., Kerzenmacher, T., Kramer, I., Mahieu, E., Mellqvist, J., Mittermeier, R. L., Notholt, J., Rinsland, C. P., Schrijver, H., Smale, D., Strandberg, A., Straume, A. G., Stremme, W., Strong, K., Sussmann, R., Taylor, J., van den Broek, M., Velazco, V., Wagner, T., Warneke, T., Wiacek, A., and Wood, S.: Comparisons between SCIAMACHY and ground-based FTIR data for total columns of $\mathrm{CO}, \mathrm{CH}_{4}, \mathrm{CO}_{2}$ and $\mathrm{N}_{2} \mathrm{O}$, Atmos. Chem. Phys., 6, 1953-1976, doi:10.5194/acp6-1953-2006, 2006.

Eck, T. F., Holben, B. N., Dubovik, O., Smirnov, A., Goloub, P., Chen, H. B., Chatenet, B., Gomes, L., Zhang, X.-Y., Tsay, S.C., Ji, Q., Giles, D. M., and Slutsker, I.: Columnar aerosol optical properties at AERONET sites in central eastern Asia and aerosol transport to the tropical mid-Pacific, J. Geophys. Res., 110, D06202, doi:10.1029/2004JD005274, 2005.

Elguindi, N., Clark, H., Ordóñez, C., Thouret, V., Flemming, J., Stein, O., Huijnen, V., Moinat, P., Inness, A., Peuch, V.-H., Stohl, A., Turquety, S., Athier, G., Cammas, J.-P., and Schultz, M.: Current status of the ability of the GEMS/MACC models to reproduce the tropospheric $\mathrm{CO}$ vertical distribution as measured by MOZAIC, Geosci. Model Dev., 3, 501-518, doi:10.5194/gmd-3501-2010, 2010.

Gimeno García, S., Schreier, F., Lichtenberg, G., and Slijkhuis, S.: Near infrared nadir retrieval of vertical column densities: methodology and application to SCIAMACHY, Atmos. Meas. Tech., 4, 2633-2657, doi:10.5194/amt-4-2633-2011, 2011.

Gloudemans, A. M. S., Krol, M. C., Meirink, J. F., de Laat, A. T. J., van der Werf, G. R., Schrijver, H., van den Broek, M. M. P., and Aben, I.: Evidence for long-range transport of carbon monoxide in the Southern Hemisphere from SCIAMACHY observations, Geophys. Res. Lett., 33, L16807, doi:2006GL026804, 2006.

Gloudemans, A. M. S., Schrijver, H., Hasekamp, O. P., and Aben, I.: Error analysis for $\mathrm{CO}$ and $\mathrm{CH}_{4}$ total column retrievals from SCIAMACHY $2.3 \mu \mathrm{m}$ spectra, Atmos. Chem. Phys., 8, 39994017, doi:10.5194/acp-8-3999-2008, 2008.

Gloudemans, A. M. S., de Laat, A. T. J., Schrijver, H., Aben, I., Meirink, J. F., and van der Werf, G. R.: SCIAMACHY CO over land and oceans: 2003-2007 interannual variability, Atmos. Chem. Phys., 9, 3799-3813, doi:10.5194/acp-9-3799-2009, 2009.

Guenther, A., Hewitt, C. N., Erickson, D., Fall, R., Geron, C., Graedel, T., Harley, P., Klinger, L., Lerdau, M., McKay, W. A., Pierce, T., Scholes, B., Steinbrecher, R., Tallamraju, R., Taylor, J., and Zimmerman, P.: A global model of natural volatile organic compound emissions, J. Geophys. Res., 100, 8873-8892, 1995.

Hopkins, J. R., Evans, M. J., Lee, J. D., Lewis, A. C., H Marsham, J., McQuaid, J. B., Parker, D. J., Stewart, D. J., Reeves, C. E., and Purvis, R. M.: Direct estimates of emissions from the megacity of Lagos, Atmos. Chem. Phys., 9, 8471-8477, doi:10.5194/acp9-8471-2009, 2009.

Huijnen, V., Williams, J., van Weele, M., van Noije, T., Krol, M., Dentener, F., Segers, A., Houweling, S., Peters, W., de Laat, J., Boersma, F., Bergamaschi, P., van Velthoven, P., Le Sager, P., Eskes, H., Alkemade, F., Scheele, R., Nédélec, P., and Pätz, H.-W.: The global chemistry transport model TM5: description and evaluation of the tropospheric chemistry version 3.0, Geosci. Model Dev., 3, 445-473, doi:10.5194/gmd-3-445-2010, 2010.

Labonne, M., Breon, F.-M., and Chevallier, F.: Injection heights of biomass burning aerosols as seen from a space borne lidar, Geophys. Res. Lett., 34, L11806, doi:10.1029/2007GL029311, 2007.

Liu, C., Beirle, S., Butler, T., Liu, J., Hoor, P., Jöckel, P., Penning de Vries, M., Pozzer, A., Frankenberg, C., Lawrence, M. G., Lelieveld, J., Platt, U., and Wagner, T.: Application of SCIAMACHY and MOPITT CO total column measurements to evaluate model results over biomass burning regions and Eastern 
China, Atmos. Chem. Phys., 11, 6083-6114, doi:10.5194/acp11-6083-2011, 2011.

Marenco, A., Thouret, V., Nedelec, P., Smit, H., Helten, M., Kley, D., Karcher, F., Simon, P., Law, K., Pyle, J., Poschmann, G., Wrede, R. V., Hume, C., and Cook, T.: Measurements of ozone and water vapour by Airbus in-service aircraft: The MOZAIC airborne program, An overview, J. Geophys. Res., 103, 2563125642, 1998.

Nedelec, P., Cammas, J.-P., Thouret, V., Athier, G., Cousin, J.-M., Legrand, C., Abonnel, C., Lecoeur, F., Cayez, G., and Marizy, C.: An improved infrared carbon monoxide analyser for routine measurements aboard commercial Airbus aircraft: technical validation and first scientific results of the MOZAIC III programme, Atmos. Chem. Phys., 3, 1551-1564, doi:10.5194/acp-3-15512003, 2003.

Ohara, T., Akimoto, H., Kurokawa, J., Horii, N., Yamaji, K., Yan, X., and Hayasaka, T.: An Asian emission inventory of anthropogenic emission sources for the period 1980-2020, Atmos. Chem. Phys., 7, 4419-4444, doi:10.5194/acp-7-4419-2007, 2007.

Redelsperger, J.-L., Thorncroft, C. D., Diedhiou, A., Lebel, T., Parker, D. J., and Polcher, J.: African Monsoon Multidisciplinary Analysis: An International Research Project and Field Campaign, B. Am. Meteorol. Soc., 87, 1739-1746, 2006.

Schultz, M. G., Backman, L., Balkanski, Y., Bjoerndalsaeter, S., Brand, R., Burrows, J. P., Dalsoeren, S., de Vasconcelos, M., Grodtmann, B., Hauglustaine, D. A., Heil, A., Hoelzemann, J. J., Isaksen, I. S. A., Kaurola, J., Knorr, W., LadstaetterWeißenmayer, A., Mota, B., Oom, D., Pacyna, J., Panasiuk, D., Pereira, J. M. C., Pulles, T., Pyle, J., Rast, S., Richter, A., Savage, N., Schnadt, C., Schulz, M., Spessa, A., Staehelin,J., Sundet, J. K., Szopa, S., Thonicke, K., van het Bolscher, M., van Noije, T., van Velthoven, P., Vik, A. F., and Wittrock, F.: REanalysis of the TROpospheric chemical composition over the past 40 years (RETRO) - A long-term global modeling study of tropospheric chemistry, Final Report, Julich/Hamburg, Germany, 2007 (published as report no. 48/2007 in the series "Reports on Earth System Science" of the Max Planck Institute for Meteorology, Hamburg, ISSN 1614-1199), 2007.
Shindell, D. T., Faluvegi, G., Stevenson, D. S., Krol, M. C., Emmons, L. K., Lamarque G. Pétron, J.-F., Dentener, F. J., Ellingsen, K., Schultz, M. G., Wild, O., Amann, M., Atherton, C. S., Bergmann, D. J., Bey, I., Butler, T., Cofala, J., Collins, W. J., Derwent, R. G., Doherty, R. M., Drevet, J., Eskes, H. J., Fiore, A. M., Gauss, M., Hauglustaine, D. A., Horowitz, L. W., Isaksen, I. S. A., Lawrence, M. G., Montanaro, V., Müller, J.-F., Pitari, G., Prather, M. J., Pyle, J. A., Rast, S., Rodriguez, J. M., Sanderson, M. G., Savage, N. H., Strahan, S. E., Sudo, K., Szopa, S., Unger, N., van Noije, T. P. C., and Zeng, G.: Multimodel simulations of carbon monoxide: Comparison with observations and projected near-future changes, J. Geophys. Res., 111, D19306, doi:10.1029/2006JD007100, 2006.

Sussmann, R. and Buchwitz, M.: Initial validation of ENVISAT/SCIAMACHY columnar CO by FTIR profile retrievals at the Ground-Truthing Station Zugspitze, Atmos. Chem. Phys., 5, 1497-1503, doi:10.5194/acp-5-1497-2005, 2005.

Warneke, T., de Beek, R., Buchwitz, M., Notholt, J., Schulz, A., Velazco, V., and Schrems, O.: Shipborne solar absorption measurements of $\mathrm{CO}_{2}, \mathrm{CH}_{4}, \mathrm{~N}_{2} \mathrm{O}$ and $\mathrm{CO}$ and comparison with SCIAMACHY WFM-DOAS retrievals, Atmos. Chem. Phys., 5, 2029 2034, doi:10.5194/acp-5-2029-2005, 2005.

van der Werf, G. R., Randerson, J. T., Giglio, L., Collatz, G. J., Kasibhatla, P. S., and Arellano Jr., A. F.: Interannual variability in global biomass burning emissions from 1997 to 2004, Atmos. Chem. Phys., 6, 3423-3441, doi:10.5194/acp-6-3423-2006, 2006. 